\title{
Author Correction: Instantaneous fibrillation of egg white proteome with ionic liquid and macromolecular crowding
}

Pankaj Bharmoria (D), Dibyendu Mondal (D), Matheus M. Pereira (D), Márcia C. Neves (D), Mafalda R. Almeida (D), Maria C. Gomes, João F. Mano, Igor Bdikin, Rute A. S. Ferreira (1), João A. P. Coutinho (D) \& Mara G. Freire (D)

Correction to: Communications Materials https://doi.org/10.1038/s43246-020-0035-0, published online 11 June 2020.

The original version of this Article did not include in Fig. 4 the panels showing the deconvoluted FT-IR spectra. These have now been added as panels $\mathrm{f}$ and $\mathrm{g}$ in Fig. 4. HTML and PDF versions of the article have been updated.

Published online: 15 July 2020

\footnotetext{
(c) Open Access This article is licensed under a Creative Commons Attribution 4.0 International License, which permits use, sharing, adaptation, distribution and reproduction in any medium or format, as long as you give appropriate credit to the original author(s) and the source, provide a link to the Creative Commons license, and indicate if changes were made. The images or other third party material in this article are included in the article's Creative Commons license, unless indicated otherwise in a credit line to the material. If material is not included in the article's Creative Commons license and your intended use is not permitted by statutory regulation or exceeds the permitted use, you will need to obtain permission directly from the copyright holder. To view a copy of this license, visit http://creativecommons.org/licenses/by/4.0/.
}

(C) The Author(s) 2020 